Prepared in cooperation with the Mississippi Department of Environmental Quality, U.S. Department of Agriculture-Natural Resources Conservation Service, Mississippi Department of Transportation, U.S. Department of Agriculture-U.S. Forest Service, and Mississippi Automated Resource Information System

\title{
Development of a Watershed Boundary Dataset for Mississippi
}

Open-File Report 2008-1198

U.S. Department of the Interior

U.S. Geological Survey 



\section{Development of a Watershed Boundary Dataset for Mississippi}

By K. Van Wilson, Jr., Michael G. Clair II, D. Phil Turnipseed, and Richard A. Rebich

Prepared in cooperation with the Mississippi Department of Environmental

Quality, U.S. Department of Agriculture-Natural Resources Conservation

Service, Mississippi Department of Transportation, U.S. Department of AgricultureU.S. Forest Service, and Mississippi Automated Resource Information System

Open-File Report 2008-1198

U.S. Department of the Interior

U.S. Geological Survey 


\section{U.S. Department of the Interior \\ KEN SALAZAR, Secretary \\ U.S. Geological Survey \\ Marcia K. McNutt, Director}

U.S. Geological Survey, Reston, Virginia: 2009

For more information on the USGS - the Federal source for science about the Earth, its natural and living resources, natural hazards, and the environment, visit http://www.usgs.gov or call 1-888-ASK-USGS

For an overview of USGS information products, including maps, imagery, and publications, visit http://www.usgs.gov/pubprod

To order this and other USGS information products, visit http://store.usgs.gov

Any use of trade, product, or firm names is for descriptive purposes only and does not imply endorsement by the U.S. Government.

Although this report is in the public domain, permission must be secured from the individual copyright owners to reproduce any copyrighted materials contained within this report.

Suggested citation:

Wilson, K.V., Jr., Clair, M.G., II, Turnipseed, D.P., and Rebich, R.A., 2009, Development of a Watershed Boundary Dataset for Mississippi: U.S. Geological Survey Open-File Report 2008-1198, 8 p. 


\section{Contents}

Abstract
Introduction
Purpose and Scope
Acknowledgments
Study Area Description
Rethods
Summary
References

\section{Figures}

1. Map showing generalized land-surface elevation, principal river basins, and two physiographic districts of Mississippi.

2. Map showing example of 12-digit subwatershed in the Upper Big Black River 8-digit subbasin in Mississippi

3. Diagram showing hierarchy of hydrologic unit codes in Mississippi..............................6

4. Map showing 8-digit subbasin, 10-digit watershed, and 12-digit subwatershed boundaries for Mississippi

\section{Tables}

1. Hydrologic unit code, basin name, outlet location, and drainage area of 8-digit subbasins, 10-digit watersheds, and 12-digit subwatersheds in Mississippi (Excelß file available only online at $h$ ttp://pubs.usgs.gov/ofr/2008/1198/ 


\section{Conversion Factors}

\begin{tabular}{|c|c|c|}
\hline Multiply & By & To obtain \\
\hline \multicolumn{3}{|c|}{ Length } \\
\hline inch (in.) & 2.54 & centimeter $(\mathrm{cm})$ \\
\hline inch (in.) & 25.4 & millimeter $(\mathrm{mm})$ \\
\hline foot $(\mathrm{ft})$ & 0.3048 & $\operatorname{meter}(\mathrm{m})$ \\
\hline mile (mi) & 1.609 & kilometer $(\mathrm{km})$ \\
\hline \multicolumn{3}{|c|}{ Area } \\
\hline acre & 4,047 & square meter $\left(\mathrm{m}^{2}\right)$ \\
\hline acre & 0.4047 & hectare (ha) \\
\hline acre & 0.004047 & square kilometer $\left(\mathrm{km}^{2}\right)$ \\
\hline square mile $\left(\mathrm{mi}^{2}\right)$ & 259.0 & hectare (ha) \\
\hline square mile $\left(\mathrm{mi}^{2}\right)$ & 2.590 & square kilometer $\left(\mathrm{km}^{2}\right)$ \\
\hline \multicolumn{3}{|c|}{ Hydraulic gradient } \\
\hline foot per mile $(\mathrm{ft} / \mathrm{mi})$ & 0.1894 & meter per kilometer $(\mathrm{m} / \mathrm{km})$ \\
\hline
\end{tabular}




\title{
Development of a Watershed Boundary Dataset for Mississippi
}

\author{
By K. Van Wilson, Jr., Michael G. Clair II, D. Phil Turnipseed, and Richard A. Rebich
}

\section{Abstract}

The U.S. Geological Survey, in cooperation with the Mississippi Department of Environmental Quality, U.S. Department of Agriculture-Natural Resources Conservation Service, Mississippi Department of Transportation, U.S. Department of Agriculture-Forest Service, and the Mississippi Automated Resource Information System, developed a 1:24,000-scale Watershed Boundary Dataset for Mississippi including watershed and subwatershed boundaries, codes, names, and drainage areas. The Watershed Boundary Dataset for Mississippi provides a standard geographical framework for water-resources and selected land-resources planning. The original 8-digit subbasins (hydrologic unit codes) were further subdivided into 10-digit watersheds and 12-digit subwatersheds-the exceptions are the Lower Mississippi River Alluvial Plain (known locally as the Delta) and the Mississippi River inside levees, which were only subdivided into 10-digit watersheds. Also, large water bodies in the Mississippi Sound along the coast were not delineated as small as a typical 12-digit subwatershed. All of the data-including watershed and subwatershed boundaries, hydrologic unit codes and names, and drainage-area data - are stored in a Geographic Information System database.

\section{Introduction}

Successful implementation of Federal regulatory programs such as the Clean Water Act (1972) and the Safe Drinking Water Act (1974) mandates that Federal, State, and local agencies, as well as scientists and consultants in the private sector, have appropriate hydrologic data to make informed decisions, complete analyses, and address water issues on a watershed basis. These hydrologic data are required to accomplish such tasks as establishing and implementing Total Maximum Daily Loads (TMDLs) and source-water protection. Drainage-area data, at the watershed scale, are not currently (2008) available in many States. Engineers need drainage-area data to design hydraulic structures, such as bridges, culverts, storm-sewer systems, and intake and effluent discharges for various industrial, manufacturing, and processing plants.
Accurate drainage-area data are needed by regulators and managers to assess the effects of proposed water use, to design and develop flood-control structures, to measure and mitigate water quality, and to develop surface-water models to assist in appropriate water-resource management decisions.

The U.S. Geological Survey (USGS) Office of Water Data Coordination, the U.S. Water Resources Council, and the USGS Resources and Land Information Program initiated the original production of the standard map series called "hydrologic unit maps," which presented codes, names, and boundaries of large watersheds (called hydrologic units) in the United States and the U.S. territories in the Caribbean areas (Seaber and others, 1987). In that national map series, the United States is divided into 21 major regions. Mississippi is contained within three of these regions (the Mississippi regions are represented by 2-digit numbers: 03, 06, and 08). These 21 regions were then subdivided into 222 subregions, 352 accounting units, and 2,150 cataloging units (each of these subdivisions also being represented by 2-digit numbers) to establish the original 8-digit hydrologic unit codes (HUC) for the United States and U.S. territories in the Caribbean area. For example, for the 8-digit cataloging unit 08060201 , the 2-digit region is 08, the 4-digit subregion is 0806, and the 6-digit accounting unit is 080602 (U.S. Geological Survey, 1977).

In the 1970s, the U.S. Department of Agriculture-Natural Resources Conservation Service (NRCS) (formerly named Soil Conservation Service) adopted the use of HUCs for all NRCS investigations and surveys. Subsequently, the NRCS initiated a national program to further subdivide cataloging units into watersheds for use in water-resource planning. The NRCS added a 3-digit extension to the 8-digit HUCs to designate watersheds as 11-digit HUCs. The trailing digit was later eliminated, and the HUC designation was changed from 11 to 10 digits. The NRCS successfully completed this program in the 1980s for Mississippi. During this same period, the USGS delineated the drainage areas of many of Mississippi's smaller streams using 1:24,000- and 1:62,500-scale topographic quadrangle sheets as base maps. These drainage areas are smaller than 1 square mile $\left(\mathrm{mi}^{2}\right)$ in many parts of the State.

In 2001, the USGS, in cooperation with the Mississippi Department of Environmental Quality (MDEQ), NRCS, the 
U.S. Department of Agriculture-Forest Service (USFS), and the Mississippi Automated Resource Information System (MARIS), began a project to develop a statewide hydrologic unit map known as the Watershed Boundary Dataset (WBD), including 10-digit watershed and 12-digit subwatershed boundaries, codes, names, and areas. A 10-digit watershed typically ranges in size from about 40,000 to 250,000 acres (62.5 to $391 \mathrm{mi}^{2}$ ), and a 12-digit subwatershed typically ranges in size from about 10,000 to 40,000 acres (15.6 to $62.5 \mathrm{mi}^{2}$ ) (U.S. Department of Agriculture, Natural Resources Conservation Services, 2001, 2004). The project would provide information on Mississippi's water resources in the form of USGS hydrologic unit boundaries for 2-digit regions, 4-digit subregions, 6-digit basins (formerly called accounting units), 8-digit subbasins (formerly called cataloging units), 10-digit watersheds, and 12-digit subwatersheds. This statewide project was an extension of an MDEQ and USGS cooperative project that began in 1999 and included the watersheds and subwatersheds of two major river basins in the State.

In 2004, the USGS, in cooperation with the Mississippi Department of Transportation (MDOT), continued work on this project as part of the existing cooperative program between these two agencies. The data collected as part of this project are required for ongoing hydrologic studies and a statewide flood-frequency study.

The completed WBD for Mississippi provides a standardized dataset to be used by water-resource managers, engineers, and planners in locating, storing, retrieving, and exchanging hydrologic data. Also, these data, in digital form, could be used in surface-water hydrologic modeling, cataloging water-data acquisition, the computation and estimation of flood frequency, and low-flow duration, as well as many other water-quality and water-use projects.

\section{Purpose and Scope}

This report presents a description of the project study area, methods used in the development of watershed and subwatershed boundaries for Mississippi, and results of this study. Data presented in this report supersede the data previously published for Mississippi by Seaber and others (1987) and the U.S. Geological Survey (1977).

\section{Acknowledgments}

Special appreciation is extended to Lon Strong and Phil Jones, USDA-NRCS, who provided technical reviews and comments during the development of the WBD for Mississippi. The authors appreciate Joyce Kellum for her long hours spent digitizing the hand-drawn lines shown on the topographic maps.

\section{Study Area Description}

Mississippi is located within the East Gulf Coastal Plain Physiographic Province and generally can be divided into two physiographic districts, the Coastal Plain Uplands and the Lower Mississippi River Alluvial Plain (known locally as the Delta) (fig. 1). The State covers $47,716 \mathrm{mi}^{2}$ and is contained within the 30- and 35-degree north latitudes and the 88- and 92-degree west longitudes. The Coastal Plain Uplands encompasses more than $40,000 \mathrm{mi}^{2}$ (about 85 percent of the State) and is predominantly pine in the lower part of the State, to pine-hardwood in other parts. The Delta contains approximately 7,000 $\mathrm{mi}^{2}$ (about 15 percent of the State), is ellipsoidal in shape, extends 200 miles (mi) north-south, and is more than $60 \mathrm{mi}$ at its widest point from east to west. The Delta extends from Vicksburg northward to the State boundary south of Memphis, Tennessee. The Delta is an area of low relief (less than 100 feet (ft) of rise in land-surface elevation from Vicksburg to Memphis) characterized by sloughs and old runs of the Mississippi River. A thick veneer of loess overlies the bedrock of the valley walls and forms an abrupt, steep border between the Delta and the Coastal Plain Uplands (Thornbury, 1965). Land-surface elevations in the State range from sea level near the coast to more than $800 \mathrm{ft}$ above sea level in the northeastern corner of the State. Mississippi's climate varies from humid to subtropical. Average annual rainfall ranges from about 50 inches in the northern part of the State to almost 70 inches near the coast (Wax, 1991).

Ten principal river basins can be defined for Mississippi. The eight largest river basins are the Big Black, Coastal Streams (Biloxi, Wolf, and Jourdan Rivers), Mississippi, Pascagoula, Pearl, South Independent Streams (Bayou Pierre, Coles Creek, Homochitto, and Buffalo Rivers), Tombigbee, and the Yazoo (fig. 1). These eight river basins are described by Strom (1998) and at http://ms.water.usgs.gov/ms_proj/eric/ index.html (accessed November 20, 2009). The remaining two river basins include a small part of the Tennessee River Basin located in the northeastern corner of the State, and the North Independent Streams Basin (Tuscumbia, Hatchie, and Wolf Rivers) that drain northward into Tennessee (fig. 1). In the Coastal Plains Uplands physiographic district, which contains all of the above-mentioned basins except the Mississippi and the Yazoo River Basins, the drainage pattern is fairly well developed. For streams in the Coastal Plains Uplands where the USGS maintains streamflow gaging stations, the median stream slope is about $10 \mathrm{feet} / \mathrm{mile}(\mathrm{ft} / \mathrm{mi})$ for streams draining less than $800 \mathrm{mi}^{2}$. The drainage pattern in the Delta area of the Yazoo River Basin is naturally not well defined and is greatly affected by anthropogenic changes such as canalization, drainage canals, flood-control levees, and other agricultural and engineering practices. The median slope for gaged streams located in the Delta is about $1 \mathrm{ft} / \mathrm{mi}$ (Landers and Wilson, 1991). Streamflow patterns are tidally influenced near the Mississippi Gulf Coast. 


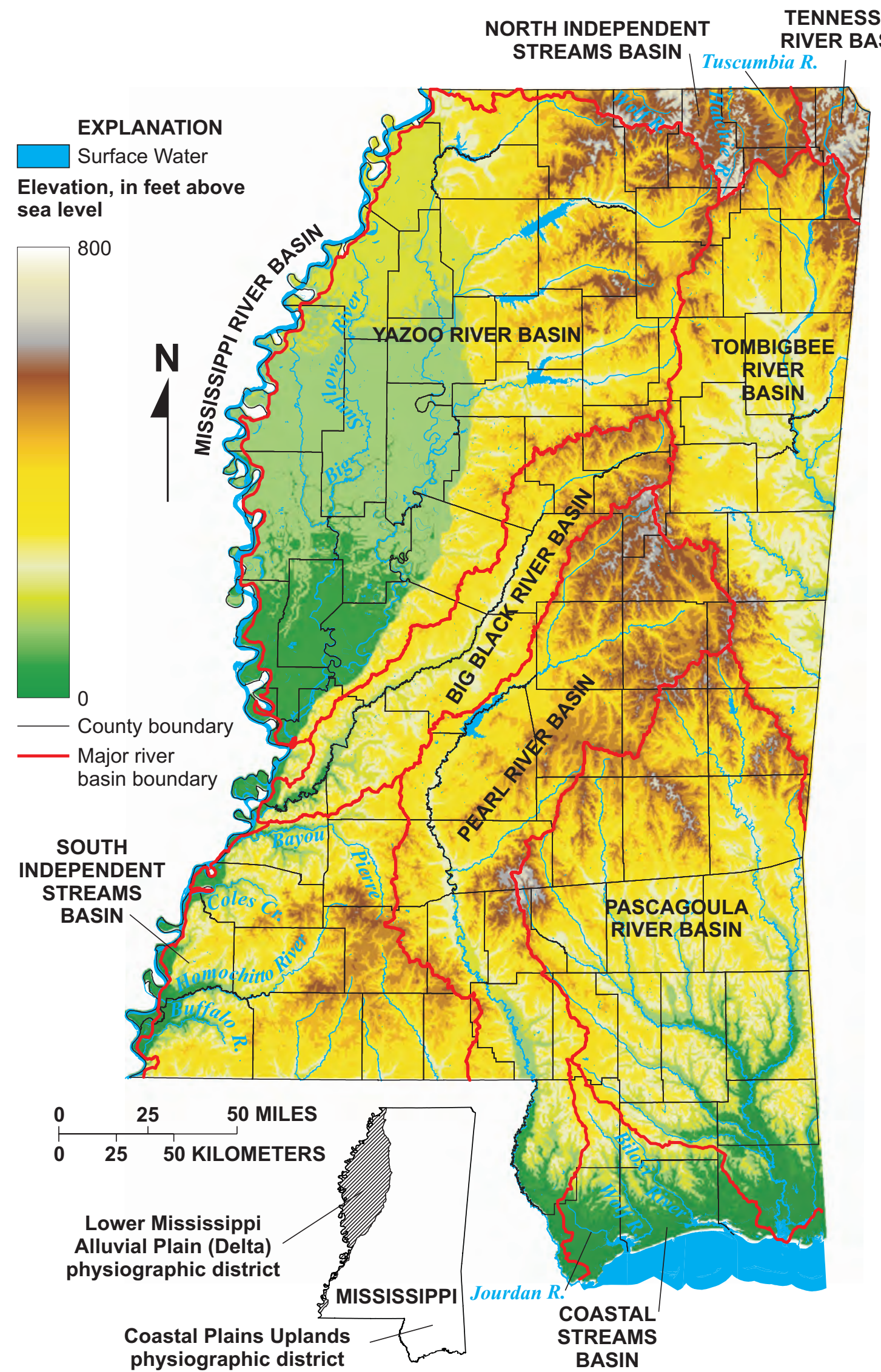

Figure 1. Generalized land-surface elevation, principal river basins, and two physiographic districts of Mississippi (modified from Strom (1998)). 


\section{Methods}

From 2001 to 2003, the 8-digit subbasins in the Coastal Plains Uplands were subdivided into 10-digit watersheds and 12-digit subwatersheds, the boundaries of which were based on 1:24,000-scale maps that contained drainage areas previously delineated by the USGS as part of ongoing water-resources investigations in the State. Drainage areas for some of these basin delineations were compiled for coastal streams by Bettandorff (1972), for Tombigbee River by Shell (1980a,b), and Pascagoula and Pearl Rivers by Shell (1981a,b,c,d,e). These compilations are available under Basin Characteristics under Historical Publications at http://ms.water.usgs.gov/ (accessed November 20, 2009).

Watershed and subwatershed boundaries were then hand-digitized and processed using geographic information system (GIS) software and stored as shape files. In some cases, 15-minute topographic quadrangles had been used in the 1970 s and 1980 s by the USGS to delineate watershed boundaries. During the current project, it was necessary to transfer watershed and subwatershed boundaries from the 15-minute topographic quadrangles to 7.5-minute topographic quadrangles (which were previously unavailable) prior to digitizing and GIS processing. The USGS and NRCS worked jointly to review and check all digitized boundaries in the Coastal Plains Uplands.

During 2003-04, the USGS subdivided the 8-digit subbasins in the Delta into 10-digit watersheds. The Delta was further subdivided into 12-digit subwatersheds only when part of a watershed was located in the Hills or Coastal Plains Uplands. The USGS used previously delineated 11-digit hydrologic unit boundaries from the NRCS and an ancillary set of boundaries provided by the U.S. Army Corps of Engineers (USACE) for the lower Big Sunflower River drainage area as a guide to delineate watershed boundaries for the Delta. The boundaries provided by the USACE were based on delineations of USGS 1:100,000-scale digital line graphs (Dave Johnson, U.S. Army Corps of Engineers, Vicksburg District, oral commun., 2003). The NRCS and USACE boundaries were transferred to 1:100,000-scale topographic quadrangle maps, and watershed boundaries were hand-drawn and digitized from those maps. The new set of watershed boundaries developed from the 1:100,000-scale maps were then transferred to 1:24,000-scale (or 7.5-minute) topographic quadrangle maps, and were refined and re-digitized according to topographic and hydrologic features at the 1:24,000 scale. Aerial photography, available in Digital Orthophoto Quadrangles (DOQs), was used as needed through the TerraServer Tool (http://www.terraservermicrosoft.com (accessed November 20, 2009)), and USACE and USGS streamflow data were used whenever possible to better define the Delta delineations.

In 2004, the USGS subdivided the 8-digit subbasins along the Mississippi River, within the levees, and along the Mississippi Gulf Coast into 10-digit watersheds and 12-digit subwatersheds. Bathymetry data shown on available National Oceanic and Atmospheric Administration Nautical Charts (scales 1:40,000 and 1:80,000) were used to subdivide the Mississippi Sound between the mainland and barrier islands into 10-digit watersheds. Aerial photography available in DOQ form was used as needed through the TerraServer Tool (http://www.terraserver.microsoft.com (accessed November 20, 2009)) to assist in the delineation of the mainland and the barrier island boundaries.

During 2004-07, the hydrologic unit boundaries for the entire State were reviewed and revised as needed. The original delineations were digitized from historical hand-drawn delineations shown on contour maps. A number of these were revised with on-screen digitizing using digital 1:24,000-scale topographic maps or Digital Raster Graphics (DRGs) and digital aerial photography or DOQs to obtain more accurate delineations. If the original delineation line was considered to follow the basin divide (roadway or ridge) within the 1:24,000-scale accuracy, it was not revised.

The USGS then assigned unique codes and names for each of the 10-digit watersheds and 12-digit subwatersheds. The numbering and naming system for each code identifies the levels of classification within 2-digit fields. An example of the numbering and naming system for a 12-digit code is given below for the Blytha Creek-Big Bywy Ditch subwatershed (080602010201):

$08-$

Region: Lower Mississippi River; drainage area about 104,000 $\mathrm{mi}^{2}$ (Seaber and others, 1987)

0806 - $\quad$ Subregion: Lower Mississippi River-Big Black River; drainage area 7,079 $\mathrm{mi}^{2}$

080602 - Basin (formerly called Accounting Unit): Big Black River-Homochitto River; drainage area $6,387 \mathrm{mi}^{2}$

08060201 - Subbasin (formerly called Cataloging Unit): Upper Big Black River; drainage area $1,479 \mathrm{mi}^{2}$

0806020102 - Watershed: Middle Bywy Creek-Big Bywy Ditch; drainage area $117 \mathrm{mi}^{2}$

080602010201 - Subwatershed: Blytha Creek-Big Bywy Ditch; drainage area $56.4 \mathrm{mi}^{2}$

An example of an assigned 12-digit subwatershed in Mississippi is shown in figure 2. Tables listing the unique codes, names, and drainage areas for each watershed and subwatershed were compiled by MARIS and USGS. The USA Contiguous Albers Equal-Area Conic Projection was used in final processing for drainage area computations, in order to be consistent with adjacent States.

The quality-assurance procedures used to delineate and code the 10-digit watersheds and 12-digit subwatersheds originally followed guidelines set forth in the Federal Geographic Data Committee proposal, Version 1.0 entitled Federal 


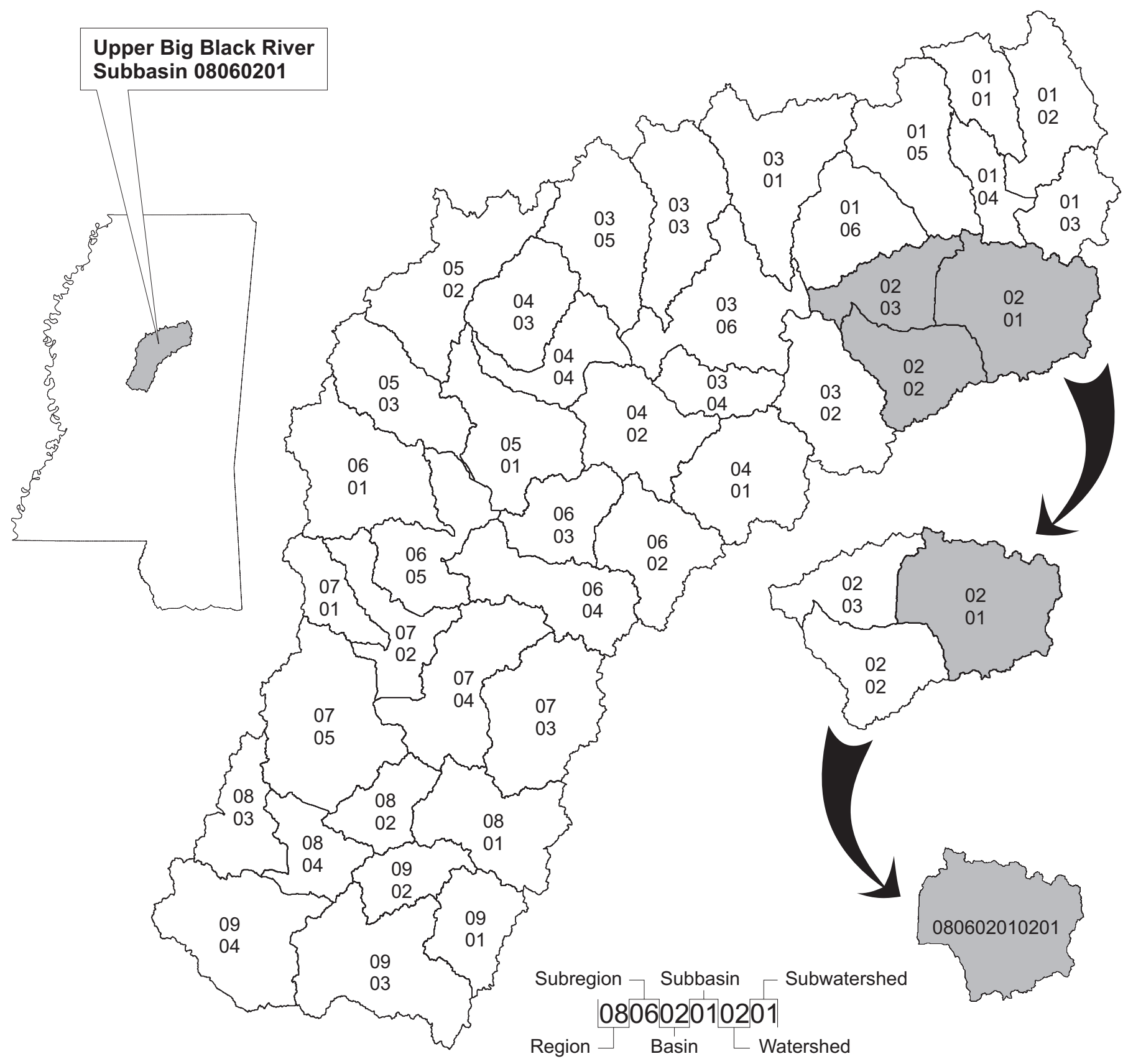

Figure 2. Example of 12-digit subwatershed in the Upper Big Black River 8-digit subbasin in Mississippi.

Standards for Delineation of Hydrologic Units Boundaries (U.S. Department of Agriculture, Natural Resources

Conservation Service, 2001), and were revised as needed during 2006-07 following guidelines set forth in Version 2.0 (U.S. Department of Agriculture, Natural Resources Conservation Service, 2004). During 2007, the USGS worked with the NRCS in Alabama and Tennessee to complete final edge matching at the State boundary. The USGS also forwarded the data to the NRCS in Louisiana in order to edge match with Louisiana at the State boundary. The USGS had previously worked with the NRCS in Arkansas to edge match with the Arkansas data. During 2009, final edge matching with Alabama, Arkansas, Louisiana, and Tennessee was completed. 


\section{Results}

Hierarchy of hydrologic unit codes and the total number of each type of hydrologic unit in Mississippi are shown in figure 3 . A total of 325 10-digit watersheds and 1,303 12-digit subwatersheds were delineated and digitized. For those contained entirely within the State, 243 10-digit watersheds ranged in size from 40,110 to 238,769 acres $\left(62.7\right.$ to $\left.373 \mathrm{mi}^{2}\right)$ and 1,149 12-digit subwatersheds ranged in size from 7,960 to 40,332 acres $\left(12.4\right.$ to $63.0 \mathrm{mi}^{2}$ ). The 12-digit range of sizes does not include eight small islands (9 to 3,320 acres) and four large water bodies (58,581 to 152,239 acres) in the Mississippi Sound. The finalized boundaries for the 8-digit subbasins, 10-digit watersheds, and 12-digit subwatersheds for Mississippi are shown in figure 4. A published 1:500,000scale WBD map shows more details of the boundaries for the 2-digit regions, 4-digit subregions, 6-digit basins, 8-digit subbasins, 10-digit watersheds, and 12-digit subwatersheds (Wilson and others, 2008). The base data for this map primarily are 1:24,000-scale, 7.5-minute topographic quadrangle sheets, but for some cases, these sheets were supplemented with DRGs and DOQs to assist in the basin delineation. The watershed and subwatershed codes, names, and drainage area sizes are listed in an Excel ${ }^{\circledR}$ spreadsheet (table 1). All of the data, including the watershed and subwatershed boundaries, hydrologic unit codes and names, and drainage-area information, are stored in a GIS database, which is available for download at http://www.ncgc.nrcs.usda.gov/products/ datasets/watershed (accessed November 20, 2009).

\section{Summary}

The USGS, in cooperation with the MDEQ, NRCS, MDOT, USFS, and MARIS, completed development of a hydrologic unit map of Mississippi including watershed and subwatershed boundaries, codes, and names in 2007. For the Coastal Plains Uplands area of Mississippi, the original 8-digit subbasins (HUCs) were further subdivided into 10-digit watersheds and 12-digit subwatersheds. These subdivisions were based on drainage area delineations made by the USGS on 1:24,000-scale topographic quadrangle sheets. The 8-digit subbasins in the Delta area of Mississippi were further subdivided to 10-digit watersheds only. The watersheds in the Delta were delineated using NRCS 11-digit watershed boundaries and ancillary boundaries provided by the USACE for the lower Big Sunflower River as a guide.

The 1:24,000-scale Watershed Boundary Dataset for Mississippi provides a standard geographical framework for water-resources and selected land-resource planning. The USGS assigned hydrologic unit codes and names for the watersheds and subwatershed, all of which were compiled in tabular form by MARIS and USGS. All of the data, including watershed and subwatershed boundaries, hydroloigic unit codes and names, and drainage-area data, are stored in a GIS database, which is available at http://www.ncgc.nrcs.usda.gov/ products/datasets/watershed (accessed November 20, 2009).

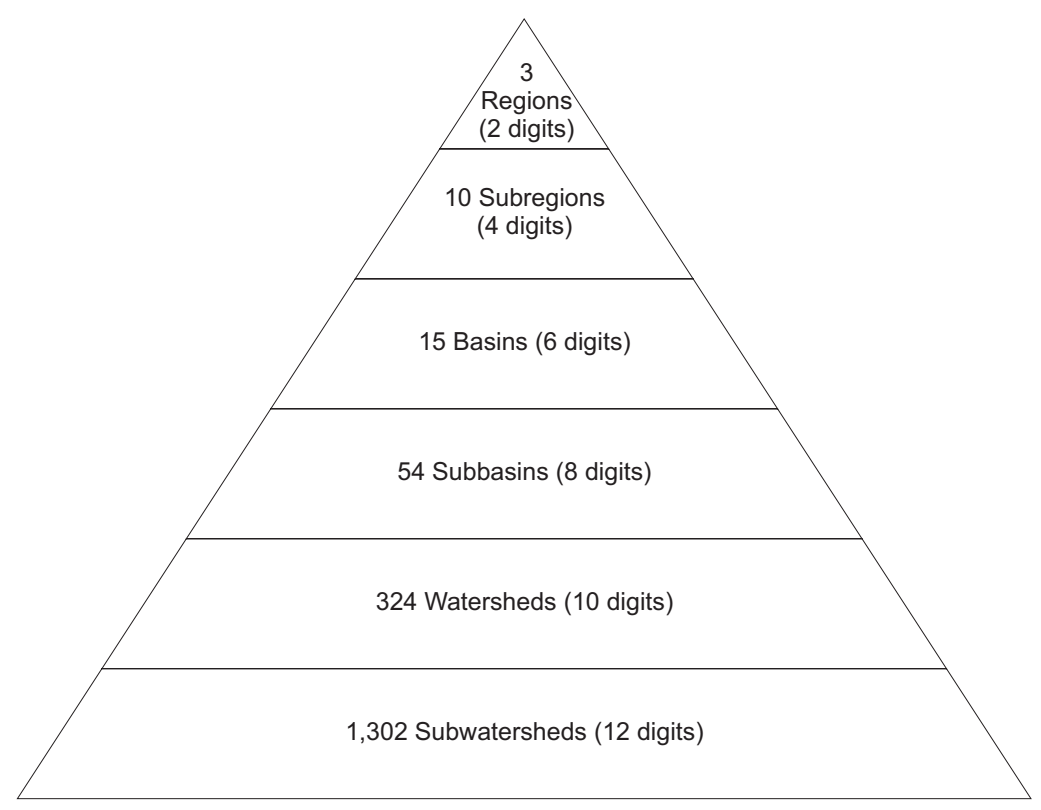

Figure 3. Hierarchy of hydrologic unit codes in Mississippi. 


\section{EXPLANATION}

Surface water

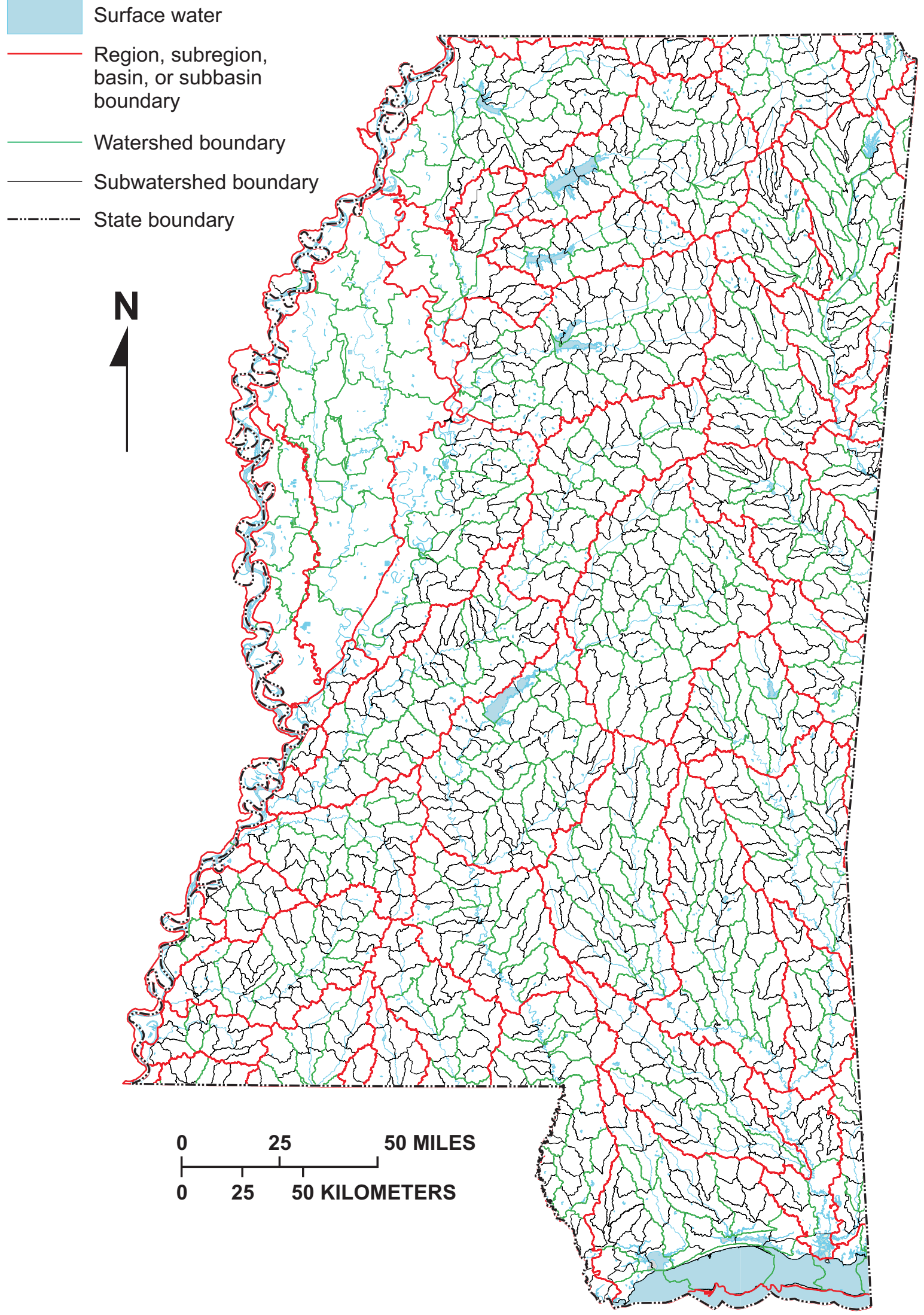

Figure 4. 8-digit subbasin, 10-digit watershed, and 12-digit subwatershed boundaries for Mississippi. 


\section{References}

Bettandorff, J.M., 1972, Selected characteristics of Mississippi streams, Part 3-Coastal River Basins: U.S. Geological Survey Bulletin 72-2, $32 \mathrm{p}$.

Landers, M.N., and Wilson, K. V., Jr., 1991, Flood characteristics of Mississippi streams: U.S. Geological Survey WaterResources Investigations Report 91-4037, 82 p.

Seaber, P.R., Kapinos, F.P., and Knapp, G.L., 1987, Hydrologic unit maps: U.S. Geological Survey WaterSupply Paper 2294, 63 p.

Shell, J.D., 1980a, Drainage areas in Tombigbee River Basin, Mississippi-Alabama, Part 1-Headwaters to above Luxapallila Creek, 277 p., accessed January 14, 2008, at http://choctaw.er.usgs.gov/new_web/reports/other_reports/ Basin_char/index.html.

Shell, J.D., 1980b, Drainage areas in Tombigbee River Basin Mississippi-Alabama, Part 2-Luxapalliala Creek to Black Warrior River and West Bank tributaries to mouth of Sucarnoochee Creek, 316 p., accessed January 14, 2008, at http://choctaw.er.usgs.gov/new_web/reports/other_reports/ Basin_char/index.html.

Shell, J.D., 1981a, Drainage areas in Pascagoula River Basin, Mississippi-Alabama, Part 1-Leaf River Basin, Headwaters to confluence with Chickasawhay River, 196 p., accessed January 14, 2008, at http://choctaw.er.usgs.gov/ new_web/reports/other_reports/Basin_char/index.html.

Shell, J.D., 1981b, Drainage areas in Pascagoula River Basin, Mississippi-Alabama, Part 2-Chickasawhay River Basin, Headwaters to Confluence of Leaf River, 190 p., accessed January 14, 2008, at http://choctaw.er.usgs.gov/new_web/ reports/other_reports/Basin_char/index.html.

Shell, J.D., 1981c, Drainage areas in Pascagoula River Basin, Mississippi-Alabama, Part 3-Pascagoula River below confluence of Leaf and Chickasawhay Rivers, 121 p., accessed January 14, 2008, at http://choctaw.er.usgs.gov/new_web/ reports/other_reports/Basin_char/index.html.
Shell, J.D., 1981d, Drainage areas in Pearl River Basin, Mississippi-Louisiana, Part 1-Headwaters through Strong River, 198 p., accessed January 14, 2008, at http://choctaw. er.usgs.gov/new_web/reports/other_reports/Basin_char/ index.html.

Shell, J.D., 1981e, Drainage areas in Pearl River Basin, Mississippi-Louisiana, Part 2-Pearl River below Strong River to mouth, 232 p., accessed January 14, 2008, at http://choctaw.er.usgs.gov/new_web/reports/other_reports/ Basin_char/index.html.

Strom, E.W., 1998, The rivers of Mississippi, chapter 34 of Marine resources and history of the Mississippi Gulf Coast, Mississippi Department of Marine Resources, v. 2, p. 425-438.

Thornbury, W.D., 1965, Regional geomorphology of the United States: New York, John Wiley \& Sons, Inc., 609 p.

U.S. Department of Agriculture-Natural Resources Conservation Service, 2001, Federal standards for delineation of hydrologic unit boundaries, Version 1.0: U.S. Department of Agriculture publication, $49 \mathrm{p}$.

U.S. Department of Agriculture-Natural Resources Conservation Service, 2004, Federal standards for delineation of hydrologic unit boundaries, Version 2.0: U.S. Department of Agriculture publication, $60 \mathrm{p}$.

U.S. Geological Survey, 1977, Hydrologic unit map-1974, State of Mississippi: U.S. Geological Survey, scale 1:500,000.

Wax, C.L., 1991, General climatology of Mississippi-Floods and droughts in National water summary 1988-89-Hydrologic events and floods and droughts: U.S. Geological Survey Water-Supply Paper 2375, p. 353-360.

Wilson, K.V., Jr., Clair, M.G., II, Turnipseed, D.P., and Rebich, R.A., 2009, Watershed boundary dataset for Mississippi: U.S. Geological Survey Scientific Investigations Map 3020: U.S. Geological Survey, scale 1:500,000. 


\section{Prepared by:}

USGS Publishing Network

Raleigh Publishing Service Center

3916 Sunset Ridge Road

Raleigh, NC 27607

For additional information regarding this publication, contact:

K. Van Wilson, Jr., Hydrologist

USGS Mississippi Water Science Center

308 South Airport Road

Jackson, MS 39208-6649

phone: 601-933-2900

email: kvwilson@usgs.gov

Or visit the Mississippi Water Science Center Web site at: http://ms.water.usgs.gov/ 
